\title{
PRICING MECHANISM AND IPO INITIAL RETURN: EVIDENCE FROM PAKISTAN STOCK EXCHANGE
}

\author{
Waqas Mehmood \\ Universiti Utara Malaysia \\ Rasidah Mohd-Rashid ${ }^{*}$ \\ Universiti Utara Malaysia \\ Abd Halim Ahmad \\ Universiti Utara Malaysia
}

\begin{abstract}
This study adds to the extent of the literature by examining the impacts of pricing mechanism and premium offered on IPO initial return in Pakistan. Cross-sectional data were gathered using 90 listed IPOs retrieved from Pakistan stock exchange. Accordingly, ordinary least squares, quantile regression, robustness regression, and stepwise regression were employed to assess the factors that influenced initial return. This study describes the intensity of initial return in light of company specific and issue specific variables. Both closing and opening prices to offer price were incorporated to measure the initial return on the initial day of trading. The outcomes showed that after the reform of book building pricing mechanism, the initial return of IPOs increased, when compared to the fixed price offerings in Pakistan. This study concludes that information from book building pricing mechanism and premium had influenced both issuer and investor in subscribing IPO.
\end{abstract}

Keywords: IPO, Initial return, Book building, Premium, Pakistan market, Information asymmetry.

Received: 16 August 2019

Accepted: 14 September 2020

\section{INTRODUCTION}

The first day of abnormal positive return (underpricing) within Initial Public Offering (IPO) has been pragmatically proven in every financial market (Mohd-Rashid, Masih, Abdul-Rahim, \& CheYahaya, 2018; Tutuncu, 2020). The anomaly of initial return is persistent, and this has also been reported in Pakistan, hence considered as a universal phenomenon (Aslam \& Ullah, 2017; Khalid \& Farhat, 2018; Sohail, Raheman, Zakaria, \& Farhat, 2018a). Despite the massive number of evidences concerning IPO initial return, it is clear that initial return is a reoccurring phenomenon in each market. In Pakistan, the highest number of IPOs were issued during 1992-1998 particularly after deregulation and liberalisation, but the financial market took a slow turn after nuclear test sanctions were imposed on Pakistan by the US (Malik, 2012). In 1999, not even a single IPO was offered, which led to constriction of the overall IPO market (Pakistan Stock Exchange-Flotation, 1999). More importantly, only 90 IPOs were offered during 2000-2017, which seemed very low,

\footnotetext{
* Corresponding author: School of Economics, Finance and Banking, Universiti Utara Malaysia, 06010 Sintok, Kedah, Malaysia. Email: m.rasidah@uum.edu.my
} 
when compared to that during the period of 1992-1998. This decreasing trend of IPOs was due to macroeconomic conditions of Pakistan, for instance, terrorist activities, political instability, social security issues, and slow industrial production growth (Mehmood, Mohd-Rashid, \& Ahmad, 2020c). Angelini and Foglia (2018) asserted that industrial production, market volatility, initial return, and interest rate affected the number of IPOs issued. Due to the effect of macroeconomic factors in Pakistan, its IPO market limited both gross domestic product (GDP) and employment growth.

Apart from macroeconomic factors, Pakistan experienced two financial crises; Badla financing in 2005 and financial global crisis in 2008. Prior to these financial crashes, intense involvement of institutional investors, commercial banks, and major market players was noted. In essence, these crashes resulted in no confidence among small investors, thus their decision to avoid investing in Pakistani capital market. After the deregulation and liberalisation period, various reforms had taken place to strengthen the Pakistani market. In this sense, book building, which was initiated in 2009, appeared to be the most noticeable mechanism to efficiently build the Pakistani market. In the book building pricing mechanism, high initial return is impossible because uninformed investors will bid with high prices, but initial return phenomenon still exists in Pakistan as several studies documented high initial return of 46\% and 51.57\% (Aslam \& Ullah, 2017; Yar \& Javid, 2014). Khalid and Farhat (2018) claimed that after the adoption of book building pricing mechanism, the initial return decreased in Sri Lanka and India, but not for the Pakistan market as higher initial return was recorded even after installation of book building pricing mechanism for new listing IPOs.

Within the context of Pakistan, past studies concerning initial return issues reported a range of significant determinants, such as offer size and price, firm size, ownership structure, information asymmetry, ex-anti-certainty, market sentiment, aftermarket risk, subscription ratio, size of private firm and government entity, issue timing, and underwriter reputation, market volatility, market capitalisation (Aslam \& Ullah, 2017; Javid \& Malik, 2016; Kayani \& Amjad, 2011; Khalid \& Nasr, 2007; Sohail, Bilal, Rukh, \& Fatima, 2018b). The Pakistan's security market size, regulatory framework, institutional setting, and efficiency of market differ from those of other developing nations. The high initial return continues to persist, hence a valid reason to explore this phenomenon within the context of Pakistan. Nevertheless, two crucial information frictions have been identified in Pakistan to affect individual investors and market sentiments, which raises this initial return phenomenon.

This first crucial friction of raised information refers to pricing mechanism. In Pakistan, the fixed price method was used to offer IPO prior to 2009, and thereafter, the book building pricing mechanism has been employed. Book building is a price determination tool based on demands of investors that operates by institutional and high net-worth investors in Pakistan. In the entire process of book building pricing mechanism, price is determined by the bidding procedure after patching up of investors' demands towards price. Through book building pricing mechanism, the maximum capital could be raised, but it would become difficult for the investors to determine the true value of the company. Hence, investors are invited to take part in the bidding process and the widening information asymmetry increases initial return. In this vein, information asymmetry amidst developing nations becomes wider due to market imperfection (Eldomiaty, 2008). Therefore, in Pakistan, the initial return is still high despite the implementation of book building pricing mechanism. On the contrary, adverse selection is also at extreme level relevant to fixed 
price. Underwriters (investment banks) used book building as their marketing campaign by involving investors to determine their opinion prior to IPO pricing, in order to attract investors via high initial return of IPO. From the book building process, information is revealed and offer price is adjusted accordingly based on market feedback upwards or downwards in the prospectus. In precise, if the offer price of IPO is adjusted upwards, the initial return will be higher comparatively to downward adjustment. Besides book building, fixed price is also used to offer IPOs in Pakistan, which is a common practice in other Asian countries, such as Hong Kong, Malaysia, and Thailand. Thus, it is essential to study the mechanism (book building) called soliciting private information from institutional investor, mainly because this study predicted that IPO initial return was affected by book building pricing mechanism due to ignorance of small investors.

It is contended that through premium in the offer price, growth opportunities are present because investors are willing to pay high premium. IPO premium is the fraction of offer price that is measured through the variance between offer price and pre-IPO book value per share (Nelson, 2003; Rasbeed, Datta, \& Chinta, 1997). IPOs are offered at par and premium, wherein higher premium indicates good quality IPO that generates more demand and higher initial return on the first day of trading. The security exchange commission of Pakistan refers to the main body for corporate setting and provides regulations regarding premium. In Pakistan, premium is charged with both fixed price and book building mechanism. As for the general public, premium can be charged from those firms, especially amidst those who tend to show their profitable record from at least one year in prospectus. Meanwhile, in other Asian countries (e.g., Bangladesh, China, and Singapore), premium is excluded from the fixed price mechanism. Based on Pakistan's listing regulations, the charged premium must not exceed the amount of private placement premium and must be disclosed in a prospectus; any underwriter who are commercial bank, investment bank and at least two financial institutions must fully underwrite the IPO offered on premium. In the same vein, underwriters who are the major party in IPOs and adequately strong to provide signal of quality IPO, may eventually attract investors with greater premium (Gounopoulos, Mazouz, \& Wood, 2019). Similarly, in the light of signalling theory, firms' quality is expressed through underwriters who tend to increase expectations of higher initial return (Bangsund, 2014).

This study argues that the method used in offering the IPO could explain the trends in attracting investors. As such, this study investigated the impacts of pricing mechanism and premium on IPO initial return. This study extends the work by Pu and Wang (2015) by incorporating the signalling factor that influences initial return. It is indeed important to investigate the factors that influenced IPO initial return within the Pakistani capital market. This research gap is bridged as this study met the following important objectives: (1) to examine the Pakistan's regulatory environment regarding IPO subscription on premium; (2) to investigate the IPO practices upon initiation of book building offering method; and (3) to identify the important factors that influenced IPO initial return in Pakistan. In line with the study objectives, this paper is structured into several sections, as follows: Section 2 presents the literature review, Section 3 describes the study methodology, Section 4 discusses the empirical analysis outcomes, and lastly, Section 5 concludes this study with several recommendations. 


\section{LITERATURE REVIEW}

In any company, IPO is one of the most far reaching events. IPO refers to the first time when shares are sold to the public and it is the most consequential method to acquire financing. Across nations, vast empirical evidences on IPO initial return are evident, hence making it clear that there are considerable volatilities for the existence of initial return phenomenon. Amongst developed financial markets, the average initial return is lower than that recorded in emerging markets (Marcato, Milcheva, \& Zheng, 2018). For instance, the initial return in Sweden was 7.68\% Abrahamson and De Ridder (2015), as well as $12.00 \%$ for Norway Marcato et al. (2018) and the USA (Guo, Wang, Seng, \& Hung, 2017). As for the initial return in Pakistan, Aslam and Ullah (2017) reported $46.00 \%$. The Pakistan's security exchange commission introduced the book building pricing mechanism in 2009 to overcome issues related to high initial return. In book building process, the final offer price does not represent high initial return because during the bidding, uninformed investors lack information regarding firm value, and hence, bid higher share price. Khalid and Farhat (2018) claimed that the initial return decreased in India and Sri Lanka after adopting the book building, but an opposing scenario is noted for Pakistan as the initial return is still high and continues to escalate. Hence, its financial market faces inefficiency from the puzzling phenomenon of initial return. Table 1.0 presents several studies that had investigated IPOs in Pakistan, which displays increasing trend of initial return despite implementation of book building.

Table 1.0: Previous studies on Pakistan's initial return.

\begin{tabular}{lccc}
\hline \hline \multicolumn{1}{c}{ Author } & Sample period & Sample size & Initial return \\
\hline Khalid and Nasr (2007) & $2000-2005$ & 50 & $35.66 \%$ \\
Sohail and Raheman (2010) & $2000-2009$ & 73 & $42.10 \%$ \\
Kayani and Amjad (2011) & $2000-2010$ & 59 & $39.87 \%$ \\
Yar and Javid (2014) & $2000-2012$ & 59 & $51.57 \%$ \\
Aslam and Ullah (2017) & $2001-2010$ & 59 & $46.00 \%$ \\
Sohail et al., (2018a) & $2000-2012$ & 83 & $39.64 \%$ \\
\hline \hline
\end{tabular}

Source: Compiled by authors

\subsection{Hypotheses Development}

In the attempt of elaborating the initial return phenomenon, a range of theoretical models have been developed. Therefore, based on the literature, several hypotheses have been formulated in this study to determine the influence of pricing mechanism and premium influences on initial return.

In the academic literature, investigation of book building was pioneered by and Benveniste and Wilhelm (1990), as they described book building process in three steps. First, the underwriter (investment bank) decides which investor has more potential to buy new offering. After that, new issues are evaluated by investors to provide demand indications to underwriter. Finally, according to investors' demands, the underwriters adjust offer price of new offerings and allocate the highest shares to the investor who projected the highest demand. To date, the IPO book-building offering method has been widely applied as a formal procedure for pricing and allocation of new offerings. In book building, the underwriter plays key role and solicit quality information from potential investor(s). Underwriters work as marketers in the book building IPO offering method to generate 
demand from investors in the primary market. Demands of investors are the fundamental assessment tool for stock valuation, and thereafter, underwriters adjust the offer price of IPO accordingly. Before making the final price, the issuers will receive much beneficial information regarding the potential investor, in which the power of an individual investor is neutralised. In the book building IPO offering method, the final set price by underwriter is lower than the closing price on the first trading day of IPO, and subsequently, the shares are under-priced (Ibbotson, 1975). Pu and Wang (2015) applied dummy variable in their study to prove that the reform of new pricing mechanism is significantly higher than the fixed price offering. In Pakistan, the book building pricing mechanism was introduced in 2009 as the official flotation of IPO offering with fixed price mechanism. The financial market setting in Pakistan differs from that in Malaysia, Hong Kong, and Singapore. In the bidding process of book building, the participation of both institutional and high net-worth investors (investor who bids for $1,000,000$ or above) reflects a unique combination of investors for bidding IPO share price. The available bidding information in preliminary prospectus is useful for investor valuation regarding IPOs subscription. This unique combination for bidding allows the investigation of the impact of IPO book building on the first day of initial return in Pakistan. Thus, the first hypothesis tested in this study is:

\section{H1. Pricing mechanism has a significantly positive influence on IPO initial return.}

From the light of signalling theory, a consumer/buyer uses market available information to be aware about the product quality prior to purchase decision. Hence, through market statistics, issuers get the opportunity to sell products at a higher price because sellers are informed about the quality and the buyer solely relies on the information available in the market. Subsequently, the buyer faces information asymmetry issue and purchases low quality product at a higher price (Akerlof, 1978). Titman and Trueman (1986) asserted that firms pay a high amount to underwriters to better certify that the firms are indeed of high quality to attract investors. The underwriter offers IPOs at premium to investors using quality tactics (Gounopoulos et al., 2019). Similarly, Mohd-Rashid, Abdul-Rahim, Che-Yahya (2019b) argued that firms having high quality underwriters indicates low risk. Thus, investors end up paying high premium for the sake of continuous growth opportunity. High premium indicates quality IPO and investors are supposed to gain high return. Premium attracts more investors and increases subscription ratio, which result in underpricing, mainly because underpricing relies on investors' demands. Regulations in Bangladesh, China, and Singapore state that premium is not charged at fixed price offering, but no regulation is imposed in Pakistan to charge premium on only book building. Therefore, premium in Pakistan is charged on both methods of offering. That being said, the second hypothesis tested in this study is;

H2: Premium has a significantly positive influence on initial return.

\section{DATA AND METHDOLOGY}

Primarily, this study determined the most efficient model in predicting the initial return phenomenon in Pakistan. As such, this study examined new listed firms on Pakistan's stock exchange. In order to attain this objective, 90 IPOs were retrieved from year 2000 until 2017 to examine the significant factors that increased the initial return in Pakistan. The secondary data for this study is already available on prospectuses and flotation. The significant data extracted from prospectus and flotation were pricing mechanism, available premium, offer price, total capital 
offered to general public, and total financial leverage. This study selected listed IPOs offered between year 2000 and 2017, especially after nuclear test sanction was imposed by the US in year 1999. This resulted in deteriorating IPO activities due to macroeconomic factors, such as terrorism, political instability, and social issues. Subsequently, in 1999, the privatization operations were merged into one Privatization Commission. During the Musharraf regime's (1999) privatization process got some momentum, resulting in the privatization of many firms that began IPO activities after 2000. Table 1.1 shows the overall number of IPOs offered, the amount raised from IPOs, as well as overpricing and underpricing for 2000-2017. During this time period, book building pricing mechanism was initiated and only 25 IPOs were offered. On the other hand, a total of 65 IPOs was offered via fixed pricing mechanism.

Table 1.1 shows the decreasing number of offered IPOs. For instance, only three IPOs were offered in 2000 and this pattern was noted for year 2017, while the highest number of offered IPOs was recorded for 2005 and 2007, which were 13 and 11 IPOs, respectively. To this end, the overall pattern displayed that issuers and investors had lost their confidence to invest in IPO market due to macroeconomic factors. During 2000-2008, the amount raised from IPOs was 80 to 250 million rupees, whereas 2008-2017 recorded IPOs worth 120 to 290 million rupees. This portrays that after implementation of book building in Pakistan market, more funds were raised similar to high initial return. In this vein, Table 1.1 depicts that underpricing intensity increased after book building adoption. After year 2009, the number of IPOs decreased, but the initial return increased comparatively in the presence of book building. Overall, the highest underpricing during 20002017 was $125 \%$, and thereafter, the second highest was $106 \%$. This displays that the overall initial return pattern increased after installation of book building because the underwriters increased the demand of IPOs via book building. As a result, higher demands generate higher initial return. In the IPO context, underpricing is considered as performance indicator, which is measured as the difference noted for stock market price at first listing day of trading by firm valuation (offer price). It is also known as 'leave money on the table' by initial shareholders. Figure 1.2 illustrates the overall IPOs offered sector-wise, wherein only investment banking and technology communication sectors offered maximum IPOs for year 2000-2017. Hence, it is clear that various factors had influenced underpricing. More importantly, after adoption of book building pricing mechanism, IPOs were offered based on investor sentiment. As a consequence, appropriate pricing of IPOs becomes difficult in Pakistan.

Table 1.1: Number of offered IPOs, amount raised, overpricing/underpricing during 2000-2017

\begin{tabular}{ccccc}
\hline \hline Year & $\begin{array}{c}\text { No. of IPOs } \\
\text { offered }\end{array}$ & $\begin{array}{c}\text { Amount raised in } \\
\text { million Rs. }\end{array}$ & $\begin{array}{c}\text { Overpricing } \\
\text { Mean }\end{array}$ & $\begin{array}{c}\text { Underpricing } \\
\text { Mean }\end{array}$ \\
\hline 2000 & 3 & 80 & $-19.815 \%$ & $23.333 \%$ \\
2001 & 4 & 94 & $0.000 \%$ & $29.643 \%$ \\
2002 & 3 & 70 & $-8.500 \%$ & $33.630 \%$ \\
2003 & 4 & 59 & $0.000 \%$ & $39.890 \%$ \\
2004 & 10 & 139 & $-2.500 \%$ & $55.778 \%$ \\
2005 & 13 & 181 & $-6.944 \%$ & $23.940 \%$ \\
2006 & 3 & 250 & $0.000 \%$ & $97.710 \%$ \\
2007 & 11 & 238 & $-22.400 \%$ & $71.570 \%$ \\
2008 & 9 & 101 & $0.000 \%$ & $142.160 \%$ \\
2009 & 4 & 120 & $-2.600 \%$ & $11.030 \%$ \\
2010 & 5 & 250 & $-4.526 \%$ & $56.429 \%$
\end{tabular}




\begin{tabular}{ccccc}
\hline \hline Year & $\begin{array}{c}\text { No. of IPOs } \\
\text { offered }\end{array}$ & $\begin{array}{c}\text { Amount raised in } \\
\text { million Rs. }\end{array}$ & $\begin{array}{c}\text { Overpricing } \\
\text { Mean }\end{array}$ & $\begin{array}{c}\text { Underpricing } \\
\text { Mean }\end{array}$ \\
\hline 2011 & 4 & 170 & $-0.843 \%$ & $32.510 \%$ \\
2012 & 3 & 129 & $0.000 \%$ & $32.570 \%$ \\
2013 & 1 & 163 & $0.000 \%$ & $50.000 \%$ \\
2014 & 5 & 195 & $0.000 \%$ & $15.210 \%$ \\
2015 & 6 & 190 & $-6.500 \%$ & $16.010 \%$ \\
2016 & 4 & 270 & $-6.810 \%$ & $106.630 \%$ \\
2017 & 3 & 290 & $-5.000 \%$ & $125.290 \%$ \\
\hline \hline
\end{tabular}

Source: Compiled by authors

Figure 1.0: Number of IPOs offered by industry from January 2000 until December 2017

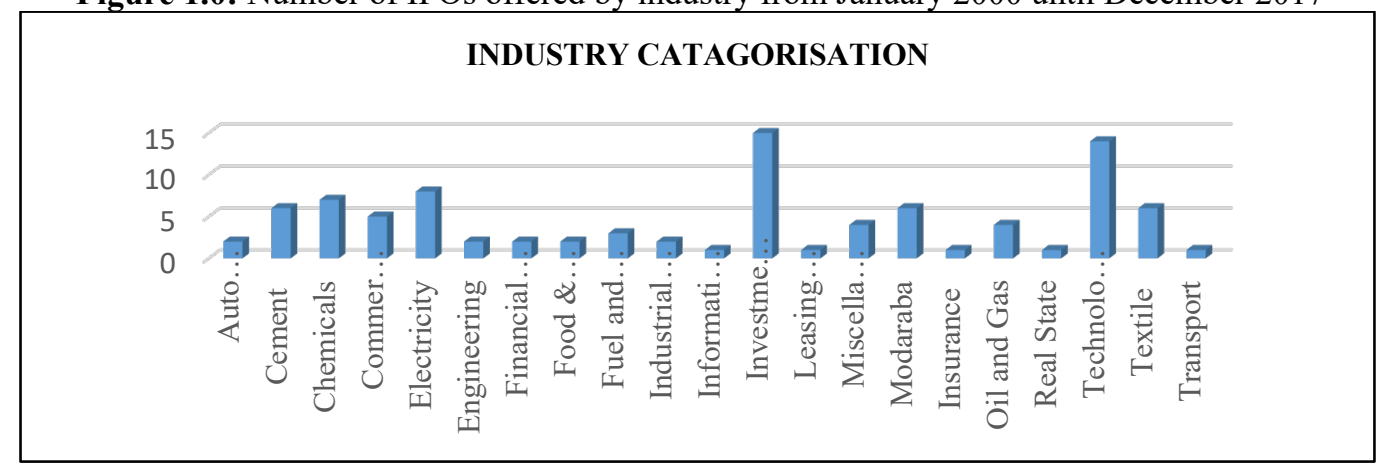

Source: Compiled by authors

In this study, the variables were divided in the categories of dependent, independent, and control variables. Initial return is the only dependent variable calculated using both closing and opening price measures. Closing price shows the change momentum of first listing day relative to offer price, but comparatively opening price measure, also known as market return, explains the opening price percentage change relative to offer price on the first day of listing (Handa \& Singh, 2017; Mohd-Rashid, Abdul Rahim, \& Yong, 2014). Along with closing price, opening price measurement offers additional insight in identifying appropriate determinants of initial return in Pakistan's IPO market. Table 1.2 presents the details of the variables embedded in this study towards meeting the study objectives.

Table 1.2: Summary of variables.

\begin{tabular}{|c|c|c|c|}
\hline Variables & Symbol & Definition & $\begin{array}{l}\text { Expected } \\
\text { signs }\end{array}$ \\
\hline $\begin{array}{l}\text { Dependent Variable } \\
\text { Initial return on first } \\
\text { listing day }\end{array}$ & $\begin{array}{l}\text { IR close } \\
\text { IR } \text { opening }\end{array}$ & $\begin{array}{l}\text { Closing price on the first trading day on the } \\
\text { secondary market minus offer price, divided by } \\
\text { offer price. } \\
\text { Opening price on the first trading day on the } \\
\text { secondary market minus offer price, divided by } \\
\text { offer price. }\end{array}$ & \\
\hline
\end{tabular}




\begin{tabular}{|c|c|c|c|}
\hline Variables & Symbol & Definition & $\begin{array}{l}\text { Expected } \\
\text { signs }\end{array}$ \\
\hline \multicolumn{4}{|l|}{ Independent Variables } \\
\hline Pricing Mechanism & DBB & $\begin{array}{l}\text { Dummy of pricing mechanism (book building } 0 \text {, } \\
\text { otherwise fixe price method } 1 \text { ). }\end{array}$ & + \\
\hline Premium & DPA & $\begin{array}{l}\text { Dummy of premium offered (without premium } 0 \text {, } \\
\text { otherwise with premium } 1 \text { ). }\end{array}$ & $+/-$ \\
\hline \multicolumn{4}{|l|}{ Control variables } \\
\hline Oversubscription & OSR & $\begin{array}{l}\text { Total number of IPOs subscribed divided by total } \\
\text { number of offered unit. }\end{array}$ & + \\
\hline Risk & Risk & $\begin{array}{l}\text { Risk is reciprocal of offer price that is calculated as } \\
1 \text { divided by offer price. }\end{array}$ & $+/-$ \\
\hline $\begin{array}{l}\text { Offered to general } \\
\text { public }\end{array}$ & LNOGP & $\begin{array}{l}\text { Natural logarithm of total shares offered to general } \\
\text { public. }\end{array}$ & $+/-$ \\
\hline Firm leverage & LNFL & $\begin{array}{l}\text { Natural logarithm of total financial liabilities at the } \\
\text { time of issuance of IPOs. }\end{array}$ & $+/-$ \\
\hline
\end{tabular}

Sources: (Mohd-Rashid, Abdul-Rahim, Che-Yahya, \& Tajuddin, 2019a); (Pu and Wang 2015); (Tajuddin, Mohd-Rashid, Khaw, \& Che-Yahya, 2019); (Mehmood, Mohd-Rashid, \& Ahmad, 2020a).

In the light of signalling theory, pricing mechanism and premium offered have signalling potential to influence initial return. Therefore, ordinary least square (OLS), quantile regression, robust least square and stepwise least square was applied in this study to determine the correlations between independent and dependent variables. The two regression equations applied in this study are listed in the following:

$I_{\text {close }}=a+\beta_{1} D_{B B}+\beta_{2} D_{P A}+\beta_{3}$ OSR $+\beta_{4} R_{\text {RSK }}+\beta_{5}$ LNOGP $_{i}+\beta_{6} \mathrm{LNFL}_{i}+\varepsilon_{i}(3.1)$

$\mathrm{IR}_{\text {opening }}=\mathrm{a}+\beta_{1} \mathrm{DBB}_{\mathrm{i}}+\beta_{2} \mathrm{DPA}_{\mathrm{i}}+\beta_{3} \mathrm{OSR}+\beta_{4} \mathrm{RISK}_{\mathrm{i}}+\beta_{5} \mathrm{LNOGP}_{\mathrm{i}}+\beta_{6} \mathrm{LNFL}_{\mathrm{i}}+\varepsilon_{\mathrm{i}}(3.2)$

This study has two independent variables: The first independent variable is pricing mechanism, which was applied as a dummy variable. It showed if the issuer used book building (represented by 0 ) or fixed price (represented by 1) to offer IPOs. The second independent variable is premium, which showed if issuers offered IPOs without premium (represented by 0 ) or with premium (represented by 1). Next, this study included four control variables: oversubscription, risk, offered capital to public, and financial leverage. Oversubscription, which was measured by the total number of IPOs subscribed and divided by the total number of offered IPOs, has a significant influence on IPO initial return. Risk is reciprocal of offer price and calculated as 1 divided by offer price. Natural $\log$ is used for the proxy of the total number of shares offered to general public. Financial leverage refers to the total liability at the time of offered IPOs, which is proxy by natural $\log$ of total liability.

From the extant literature, justification of control variables was drawn. For instance, investor demands mean pre-listing demand of IPOs estimated via oversubscription ratio (Mehmood, MohdRashid, \& Ahmad, 2020b). According to Tutuncu (2020), initial return is associated with higher demand of new listed IPOs. As for risk of IPO, newly listed firms are riskier, when compared to older firms, mainly because new listed firms have more uncertainty and especially, less expectations of good future performance (Bansal \& Khanna, 2013). Uninformed investors (general public) are not informed about the external operations, opportunities, and risks associated to the firms. Therefore, high participation of institutions provides signal of quality due to low 
participation of uninformed investors. Deb and Marisetty (2010) claimed that individual sentiment financial leverage is an important accounting variable and it has a direct link with initial return.

\section{FINDINGS AND DISCUSSION}

Table 1.3 presents the descriptive results of all the study variables. The statistical results contain mean, median, maximum, minimum, standard deviation, and statistical sample size. The statistical results show that the mean value of initial return (underpricing) is $33.23 \%$ for 2000-2017, while the highest initial return is $228 \%$ and the minimum is $-0.1502 \%$. This signifies that Pakistan had higher initial return than other emerging countries, such as Malaysia Che-Yahya, Abdul-Rahim, and Mohd-Rashid (2018) and India Handa and Singh (2017) with 28.20\% and 22.90\% underpricing, respectively. The high variation in initial return of IPOs in Pakistan appears to be the basic motivation to study factors that influenced the first trading day of return. Hence, book building adoption influenced the demand of investors and increased initial return. 





Table 1.3 shows $25.26 \%$ of mean value for dummy variable DBB. Similarly, DPA scored $51.57 \%$ mean value. The highest IPOs were offered during 2000-2009, but after that period, IPO activities reduced tremendously due to macroeconomic factors. In the start of 2009, book building was introduced in Pakistan's IPO market and the maximum number of IPOs was offered via fixed price mechanism. More importantly, after implementing the book building pricing mechanism, the initial return increased due to information asymmetry, which seemed common across Pakistan. The developing nations also reported higher information asymmetry due to market imperfection (Eldomiaty, 2008). Book building pricing mechanism is also called 'demand-generating tool' because it offers good opportunities for issuers to gain maximum proceeds. Hence, initial return is considered as compensation due to the involvement of underwriter through informational efficiency during the pricing process. As for premium, over the book value; IPOs were priced with significant premium in Pakistan. The IPO market condition influenced the IPO price, which included a premium in the offer price.

The control variables, such as OSR result, showed minimum 0.973 times and maximum 17.45 times. On average, the OSR result was 2.563 times, indicating that OSR ratio displayed huge variation. Pakistan had lower OSR relative to other countries, such as Malaysia, which was higher by 30.45 times (Tajuddin, Mohd-Rashid, Abdullah \& Abdul-Rahim, 2015). IPOs are associated with various risk levels, such as the minimum risk level reported at $0.043 \%$, while the maximum risk level was $11 \%$, and on average, $6.8 \%$. The results indicate that a low level of risk is associated with low offer price of IPOs, while higher risk level is linked with higher offer price. The offered capital to the general public (uninformed investors) is another essential individual owner who does not participate in pricing process. Based on the descriptive outputs, the minimum value of general public holdings was PKR 16,249,1000 and the maximum was PKR 2,195,900,000, while the mean value was $188,125,000$. Financial leverage is the financial debt position of issuers at the time of IPO offerings in the market, which explains that more level of debt means higher leverage that directly affects the overall operations of a company. As such, the minimum value of financial leverage was PKR 10,890,100, and the highest value was PKR 24,837,400,000, while the average value was PKR 1,894,830,000; indicating the high financial leverage in Pakistan that negatively affected earnings per share.

Figure 1.1 illustrates the total number of IPOs offered, oversubscription, and initial return on the first day of trading, which explain the trend from January 2000 until December 2017. Pakistan displayed rich IPOs activities prior to 1999 sanctions, but the continuous deterioration in IPO activities after that, especially after the implementation of book building. In Pakistan, fixed price and book building are used to offer IPOs, but before 2009; only fixed price mechanism was employed to offer IPO, wherein the number of offered IPOs was more prior to 2009. Besides IPO activities, oversubscription initial return increased continuously after the adoption of book building, which appears as very interesting in Pakistan. Under book building pricing mechanism, the possibility of initial return is very low because uninformed investors lack quality information, hence they bid for higher share price. Nevertheless, capturing investors' demand through book building is possible, thus leading to higher initial return in Pakistan. In this vein, Khalid and Farhat (2018) asserted that after adopting the book building pricing mechanism in Sri Lanka and India, their initial return intensity decreased, but in Pakistan; initial return became higher. 
Figure 1.1: Number of IPO offered, oversubscription, and initial return for 2000-2017

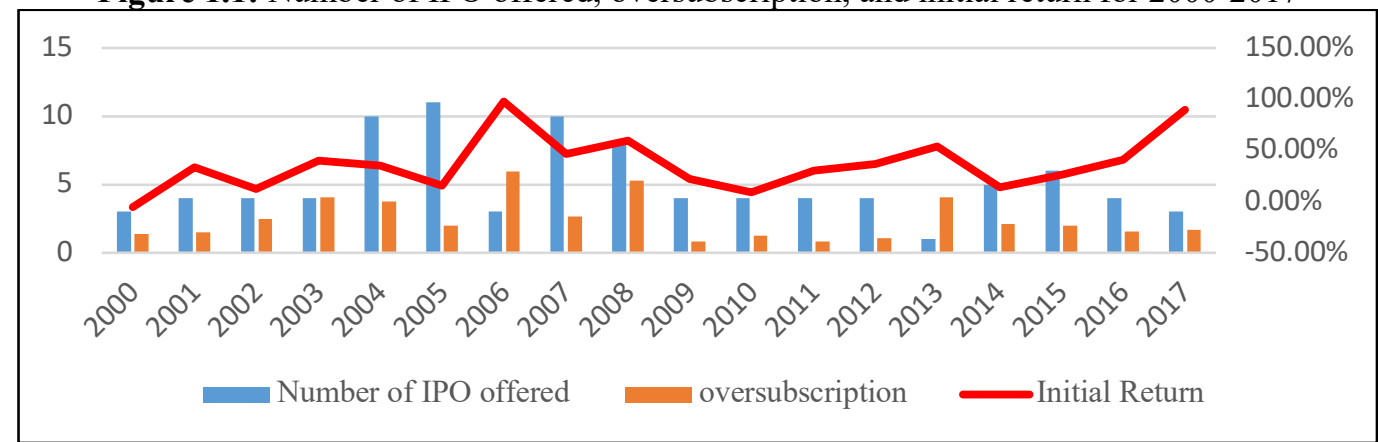

Source: Compiled by authors

Table 1.4 presents the outcomes from the correlation analysis. The results show that DPA is negatively correlated, while DBB and OSR are positively correlated with higher correlation coefficient. The findings describe absence of multicollinearity problem, mainly because all the determining variables had less than 0.62 pairwise correlation. This reflects that strong correlation changes the effects of an individual variable on dependent variable (Maddala \& Lahiri, 1992). Overall, the result reports significant correlation, except for LNFL.

Table 1.4: Pearson correlation analysis

\begin{tabular}{lcccccc}
\hline \hline & IR & DBB & DPA & OS & RISK & LNOGP \\
\hline DBB & $0.0904^{* *}$ & & & & & \\
DPA & $-0.1760^{* *}$ & $0.0871^{* *}$ & & & & \\
OSR & $0.6164^{* *}$ & -0.1663 & $0.0679^{* *}$ & & & \\
RISK & -0.0853 & -0.3493 & -0.6263 & $-0.0709^{* *}$ & & \\
LNOGP & -0.0239 & -0.2484 & -0.1143 & -0.1709 & 0.0165 & \\
LNFL & 0.0028 & 0.1099 & 0.0650 & 0.0039 & -0.1356 & 0.1712 \\
\hline \hline
\end{tabular}

Notes: $* *$ indicates significant at $5 \%$ and $* * *$ indicates significant at $1 \%$. IR is initial raw return that is calculated by closing price on the first trading day on the secondary market minus offer price, divided by offer price. DBB is dummy of pricing mechanism (book building 0, otherwise fixed price method 1). DPA is dummy of premium offered (without premium 0, otherwise with premium 1). OSR is total number of IPOs subscribed divided by total number of offered unit. Risk is computed from 1 divided by offer price of the first day of listing. LNOGP is the total amount of shares offered to the public. Risk is computed from 1 divided by offer price of the first day of listing. LNFL is financial leverage with long-term liability during IPO offering. 


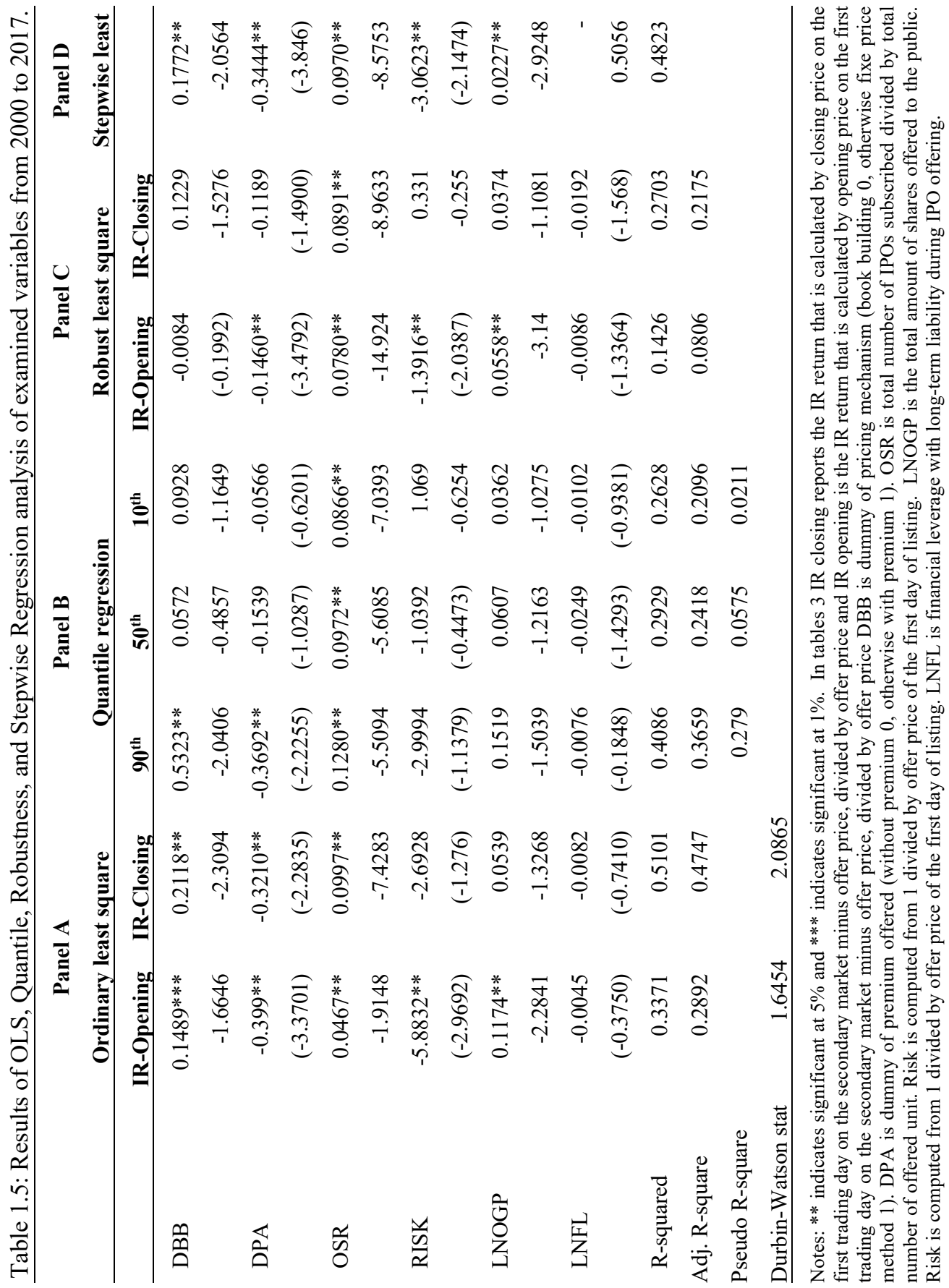


Table 1.5 presents the outcomes obtained from cross-sectional, quantile, robustness regression, and stepwise analyses of all the determining variables. In order to meet the study objectives, the crosssectional regression analysis determined the roles of pricing mechanism and premium to explain the occurrence of higher initial return in Pakistan. In the cross-sectional analysis, data autocorrelation existed, and Durbin Watson is the most useful source to identify autocorrelation. In this study, the cross-sectional regression generated dual results based on IR closing and IR opening. Therefore, Panel A reports Durbin Watson IR closing (2.086) and IR opening (1.6454). The generated results explain that autocorrelation problem existed more in $\mathrm{IR}_{\text {closing. The correlation analysis result }}$ presented in Table 1.4 is consistent with the Durbin Watson result. Furthermore, Panel A reports adjusted $\mathrm{R}^{2}$ square of IR closing at $47 \%$ and IR opening at $28 \%$, which express the overall variation in initial return. The result suggests that IR closing has more contribution than $\mathrm{IR}_{\text {opening. Table }} 1.5$ shows that the DBB dummy variable is indeed significant to explain initial return at (sig.= 0.0234 ) and the coefficient value is 0.21185 . This result indicates that initial return is significantly higher in Pakistan after the implementation of book building. This result is similar to that reported in past studies (Pu \& Wang, 2015; Song, Tan, \& Yi, 2014).

Based on the listing regulation adopted in Pakistan, institutional investors have maximum $75 \%$ holding proportion of new offerings and $25 \%$ shares allocation to the general public. This means; the highest quantity of shares is sold to institutional investors, which reflects humongous proportion. Under the book building offerings, underwriters have a preferential allocation to raise oversubscription of IPOs because with $75 \%$ allocation of institutions, underwriters can raise information from informed investors. Therefore, underpricing depends on the underwriters' discretion to favour uninformed investors, wherein underpricing is compensation to reveal positive information (Mazouz, Mohamed, Saadouni, \& Yin, 2017). In this study, premium appeared negatively significant to explain initial return of IPO. This result indicates that large firm offerings higher premium as compared to small firms that show lower assets volatility and uncertainty in their value. Thus, firms having higher premium offerings lower underpricing due to low information asymmetry. This result is supported by (Chhabra, Kiran, \& Sah, 2017). Similarly, Rasbeed et al. (1997) investigated the influential factors of IPO premium price and reported that price of premium is significant with risk of IPO, which can lead to higher initial return for initial investors. Hence, IPOs are offered at par and premium, while higher premium reflects good quality of IPO to generate more demand and higher initial return on the first day of trading.

The justification for the control variables has been drawn from the extant IPO literature. OSR is significant with initial return, which is similar to that reported elsewhere (Kayani \& Amjad, 2011; Khalid \& Raheman, 2009). This study suggested that initial return relies on the demand of IPOs. According to Mehmood et al., (2020a), investors' demand increases due to information heterogeneity, which can result in increased initial return. Furthermore, the risk of IPOs is negatively associated with initial return. This result is contrast with (Mohd-Rashid et al., 2014). Thus, it is suggested that risk and return are the major concerns of investors' attitude towards IPOs investment. LNOGP seemed significant to explain initial return, which is consistent with (Khalid \& Raheman, 2009). This study argued that Pakistan has low portion of general public holding regulations. Therefore, high involvement of institutional investors gives signal of quality IPO, which tends to increase initial return. LNFL, however, is insignificant to explain initial return. Thus, financial leverage is not an IPO success indicator because investors do not care about the leverage level of firms. 
Next, Panel B of Table 1.5 reports the relationship of initial return through quantile regression method. The quantile regression is a powerful tool used to describe the characteristics of dependent variable at varied levels for more accurate results (Angrist \& Pischke, 2008). Based on a prior model proposed by Koenker and Bassett (1978), this study used the quantile regression to determine robustness. The effects of the independent variable are described through the coefficient on initial return of IPO. Based on the reported results, DBB and DPA are positively significant at $90^{\text {th }}$ percentile, but insignificant at $50^{\text {th }}$ and $10^{\text {th }}$ percentile. OSR is the only variable that is significant at $90^{\text {th }}, 50^{\text {th }}$, and $10^{\text {th }}$ quantile. This signified that these significant variables are stronger upon initial return of IPO.

Panel C of Table 1.5 reports the relationship of initial return through the robustness regression method. Robustness regression is used to estimate results after omitting outliers from the dataset to gain results without error. The findings were reported based on IR closing and IR opening initial return measurements. DBB and DPA are insignificant, but OSR is only significant in IR closing measurement. Meanwhile, DBB is insignificant, whereas DPA, OSR, RISK, and LNOGP are significant to explain initial return of IPO in IR opening measurement. The result explains that these determinants are stronger in explaining initial return. Lastly, Panel D reports the stepwise regression to further estimate the relationship of initial return through the significance of individual variables. Through stepwise regression, 'hunch' predictors are possible to identify true determinants. The result designates the variances in the relationships of the individual variables. According to the reported results, DBB, OSR, and LNOGP are positively significant in describing IPO initial return, while negatively significant for DPA and RISK.

\section{CONCLUSION}

This paper examined the issues of pricing mechanism and premium in describing the initial return phenomenon in Pakistan's IPO market. This study hypothesised that pricing mechanism and premium offered signals of good quality IPO because the book building pricing mechanism demands assessment tool to adjust offer price accordingly. High premium shows higher growth to investors in terms of quality IPO. Hence, in this study, in testing the hypotheses, four other variables were controlled in order to determine the influence of IPO initial return. A total of 90 IPOs listed on Pakistan's stock exchange were used as study sample deriving from January 2000 until December 2017.

The results indicate that pricing mechanism and premium had significant effect on IPO initial return. This implies that book building is a price determination tool based on investors' demands and operated by institutional and high net-worth individual investors in Pakistan. The entire process of book building is determined by the bidding procedure after patching up investors' demands towards the price. The investors pay high premium for the sake of continuous growth opportunity. Thus, the findings of this study indicate that book building pricing mechanism and premium offer signals of firm quality and influence the initial return of IPOs. Furthermore, oversubscription, risk associated with IPO, and offer of capital to the general public displayed significant influence on initial return of IPO. New listing firms issuing IPOs and their performances relied on price momentum in Stock Exchange. In this study, new and additional evidence are provided in terms of information, which is beneficial for investors in making the accurate decision. More importantly, the results exhibit that the influential factor that gives signals in book building tends to raise IPO 
initial return. From the empirical findings, IPOs offered from book building pricing mechanism must ensure important disclosure information of the issuer that might affect the subscribing decision of IPO.

Based on the empirical findings, this study provides significant implications, such as investors should be more concerned about offer price from book building price mechanism because demand generated in book building pricing mechanism has an important bearing on IPO pricing. Second, policymakers and regulators may utilise informative findings from this study to deal with issuers to disclose information clearly in the prospectus. Finally, this study offers future research avenue to others by providing further extension with other variables of IPO from the literature, specifically for those countries where book building appears to be the most acceptable method in offering IPOs. This study recommends that other macroeconomic institutional quality variables may be considered, such as economic outputs (inflation, deflation, GDP), interest rate, corruption, rule of law, regulatory quality, government effectiveness, and political stability, as potential determinants of IPO initial return. This study suggests that further development of the existing literature is possible with the availability of data, such as increase in sample size and use of other useful proxies of the given variables.

\section{ACKNOWLEDGEMENT}

The authors are grateful to the anonymous referees of the journal for their extremely useful suggestions to improve the quality of the paper. The authors also would like to acknowledge their

gratitude for funding from the Fundamental Research Grant Scheme FRGS/1/2018/SS01/UUM/02/7) (S/O Code: 14203) provided by the Ministry of Higher Education, Malaysia.

\section{REFERENCES}

Abrahamson, M., \& De Ridder, A. (2015). Allocation of shares to foreign and domestic investors: Firm and ownership characteristics in Swedish IPOs. Research in International Business and Finance, 34, 52-65.

Akerlof, G. A. (1978). The market for "lemons": Quality uncertainty and the market mechanism. Uncertainty in economics, 235-251.

Angelini, E., \& Foglia, M. (2018). The relationship between IPO and macroeconomics factors: An empirical analysis from UK market. Annals of Economics and Finance, 19(1), 319-336.

Angrist, J. D., \& Pischke, J.-S. (2008). Mostly harmless econometrics: An empiricist's companion. New Jersey: Princeton University Press.

Aslam, U., \& Ullah, S. (2017). Determinants of IPO short run and long run performance: A case study on the listed firm of Pakistan Stock Exchange. Paradigms: A Research Journal of Commerce, Economics, and Social Sciences, 11(2), 165-172.

Bangsund, L. (2014). IPO valuation and investment bank reputation: evidence from a beauty contest. Journal of Applied Finance, 24(2), 52-60 . 
Bansal, R., \& Khanna, A. (2013). Vector auto-regressive analysis of determinants of IPO underpricing: empirical evidence from Bombay Stock Exchange. Global Business Review, 14(4), 651-689.

Benveniste, L. M., \& Wilhelm, W. J. (1990). A comparative analysis of IPO proceeds under alternative regulatory environments. Journal of Financial Economics, 28(2), 173-207.

Che-Yahya, N., Abdul-Rahim, R., \& Mohd-Rashid, R. (2018). The influence of" offer for sale" by existing shareholders on investors' reaction in the IPO immediate aftermarket. Business and Economic Horizons, 14(4), 818-828.

Chhabra, S., Kiran, R., \& Sah, A. N. (2017). Information asymmetry leads to underpricing: validation through SEM for Indian IPOs. Electronic Library and Information Systems, 51(2), 116-131.

Deb, S. S., \& Marisetty, V. B. (2010). Information content of IPO grading. Journal of Banking and Finance, 34(9), 2294-2305.

Eldomiaty, T. I. (2008). Determinants of corporate capital structure: evidence from an emerging economy. International Journal of Commerce and Management, 17(2), 25-43.

Gounopoulos, D., Mazouz, K., \& Wood, G. (2019). The consequences of political donations for IPO premium and performance. SSRN eLibrary.

Guo, Y., Wang, T., Seng, J. L., \& Hung, S. S. (2017). The effect of disclosure patterns of risk factors in prospectus on the relation between strategic alliances and underpricing of biotechnology IPOs. Journal of Applied Business Research, 33(3), 509-520.

Handa, R., \& Singh, B. (2017). Performance of Indian IPOs: An Empirical Analysis. Global Business Review, 18(3), 734-749.

Ibbotson, R. G. (1975). Price performance of common stock new issues. Journal of Financial economics, 2(3), 235-272.

Javid, A. Y., \& Malik, H. (2016). Performance and capital structure of IPOs in Pakistan from 2000 to 2015. Financial Innovation, 2(1), 14-33.

Kayani, S., \& Amjad, S. (2011). Investor interest, under-pricing and trading volume in Pakistan secondary market. Business and Economics Journal, 20(BEJ-39), 1-15.

Khalid, S. M., \& Farhat, R. (2018). What happened to the investors of South Asian countries while investing in the newly listed firms: A new approach? Journal of Economics, Business and Management, 6(4), 150-154.

Khalid, S. M., \& Nasr, M. (2007). Performance of initial public offerings in Pakistan. International Review of Business Research Papers, 3(2), 420-441.

Khalid, S. M., \& Raheman, A. (2009). Determinants of under-pricing of IPOs regarding financial \& non-financial firms in Pakistan. European Journal of Economics, Finance and Administrative Sciences, 15(1), 62-73.

Koenker, R., \& Bassett, G. (1978). Regression quantiles. Econometrica: Journal of the Econometric Society, 46(1), 33-50.

Maddala, G. S., \& Lahiri, K. (1992). Introduction to econometrics: Macmillan: New York.

Malik, N. (2012, June 2-3). Economic sanctions imposed on Pakistan and their impact. Paper presented at the International Conference on Innovation, Trade and Economics (ICITE), Hong Kong.

Marcato, G., Milcheva, S., \& Zheng, C. (2018). Market integration, country institutions and IPO underpricing. Journal of Corporate Finance, 53, 87-105.

Mazouz, K., Mohamed, A., Saadouni, B., \& Yin, S. (2017). Underwriters' allocation with and without discretionary power: Evidence from the Hong Kong IPO market. International Review of Financial Analysis, 49, 128-137. 
Mehmood, W., Mohd-Rashid, R., \& Ahmad, A. H. (2020a). Impact of pricing mechanism on IPO oversubscription: evidence from Pakistan stock exchange. Pacific Accounting Review, $32(2), 1-16$.

Mehmood, W., Mohd-Rashid, R., Che-Yahya, N., \& Ong, C. Z. (2020b). Determinants of heterogeneity in investors' opinions on IPO valuation: evidence from the Pakistan stock market. Review of Behavioral Finance. doi: 10.1108/RBF-04-2020-0078.

Mehmood, W., Mohd-Rashid, R., \& Ahmad, A. H. (2020c). The variability of IPO issuance: evidence from Pakistan Stock Exchange. Global Business Review, 1-16. doi: 10.1177/0972150920929198.

Mohd-Rashid, R., Abdul-Rahim, R., \& Che-Yahya, N. (2019b). The influence of information asymmetry on IPO lock-up provisions: evidence from Malaysian market. Global Business Review, 20(3), 1-14.

Mohd-Rashid, R., Abdul-Rahim, R., \& Yong, O. (2014). The influence of lock-up provisions on IPO initial returns: Evidence from an emerging market. Economic Systems, 38(4), 487-501.

Mohd-Rashid, R., Masih, M., Abdul-Rahim, R., \& Che-Yahya, N. (2018). Does prospectus information matter in IPO pricing? Journal of Islamic Accounting and Business Research, 9(4), 514-530.

Mohd-Rashid, R., Abdul-Rahim, R., Che-Yahya, N., \& Tajuddin, A. H. (2019a). Impact of a regulatory change on initial performance of IPOs. Afro-Asian Journal of Finance and Accounting, 9(3), 332-348.

Nelson, T. (2003). The persistence of founder influence: Management, ownership, and performance effects at initial public offering. Strategic management journal, 24(8), 707724.

Pakistan Stock Exchange-Flotation (1999). Pakistan stock exchange. Retrieved from www.psx.com.pk/psx/resources-and-tools/listings/listings-history.

$\mathrm{Pu}, \mathrm{D} .$, \& Wang, S. (2015). The impact of pricing mechanism reform on underpricing of initial public offerings in China. Applied Economics Letters, 22(14), 1144-1149.

Rasbeed, A., Datta, D. K., \& Chinta, R. R. (1997). Determinants of price premiums: A study of initial public offerings in the medical diagnostics and devices industry. Journal of Small Business Management, 35, 11-23.

Sohail, M., Raheman, A., Zakaria, M., \& Farhat, R. (2018a). IPO underpricing phenomenon on the Karachi stock exchange. Argumenta Oeconomica, 41(2), 225-255.

Sohail, M., Bilal, H., Rukh, L., \& Fatima, S. (2018b). Determinants of underpricing of initial public offerings and its long run performance in Pakistan. Pakistan Journal of Social Sciences, 38(2), 747-755.

Sohail, M. K., \& Raheman, A. (2010). Examining the short-run IPOs performance in state of economy: Normal, boom \& recession. International Research Journal of Finance and Economics, 35, 173-186.

Song, S., Tan, J., \& Yi, Y. (2014). IPO initial returns in China: Underpricing or overvaluation? China Journal of Accounting Research, 7(1), 31-49.

Tajuddin, A. H., Mohd-Rashid, R., Abdullah, N. A. H., \& Abdul-Rahim, R. (2015). An empirical examination of over-subscription in the Malaysian IPO market. International Journal of Economics and Management, 9(1), 81-102.

Tajuddin, A. H., Rashid, R. M., Khaw, K. L.-H., \& Yahya, N. C. (2019). Shariah-compliant status and investors' demand for IPOs: the effects of information asymmetry. International Journal of Islamic and Middle Eastern Finance and Management, 12(4), 489-508. 
Titman, S., \& Trueman, B. (1986). Information quality and the valuation of new issues. Journal of Accounting and Economics, 8(2), 159-172.

Tutuncu, L. (2020). Valuation and underpricing of Turkish IPOs. Journal of Business Economics and Management, 21(1), 157-179.

Yar, M. M. S., \& Javid, A. Y. (2014). Liquidity Benefits from Underpricing: Evidence from Initial Public Offerings Listed at Karachi Stock Exchange. PIDE Working Papers 2014 No. 101, SSRN eLibrary. 